\title{
A description of Anoplostoma nhatrangensis sp.n. from mangrove habitats of Nha Trang, Central Vietnam, with a review of the genus Anoplostoma Bütschli, 1874 (Nematoda: Enoplida)
}

\author{
Alexei V. Tchesunov ${ }^{1}$, Nguyen Vu Thanh ${ }^{2}$ \\ ${ }^{I}$ Department of Invertebrate Zoology, Faculty of Biology, Moscow State University, Moscow \\ 119991,Russia.email: AVTchesunov@yandex.ru \\ ${ }^{2}$ Institute of Ecology and Biological Resources (IEBR), Vietnam Academy of Science and Technol- \\ ogy, 18 Hoang Quoc Viet Rd., 10000 Hanoi, Vietnam.
}

\begin{abstract}
Anoplostoma nhatrangensis sp.n. is described from a degrading mangrove habitat in the Nha Trang area, Central Vietnam. The new species is characterized by relatively long outer labial setae (81-120\% c.b.d.); relatively long tail with longer posterior cylindrical portion (c 5.71-6.92, c' 8.96-11.8, distal tail part 63-90\%); males without preanal bursal papillae and only a minute postanal bursal papilla besides the posterior bursal spine. Anoplostoma nhatrangensis sp.n. is most similar to the $A$. heterurum differing in certain morphometric values: a bit more stout body (a 33-45 versus 56 ), and relatively longer tail (c 5.9-6.6 versus 11 and c' 10-12 versus 6.5) with greater posterior slender cylindrical portion (82-90 versus 75\%). A short taxonomic review of the Anoplostoma species is proposed. The genus contains twenty nominal species: fourteen of them are considered as valid; $A$. brevispiculum is considered as a species incertae sedis because its characters do not fit the generic diagnosis, A. demani as a species inquirenda because of incomplete data of the original description and $A$. macrospiculum as a junior synonym of A. sunderbanae. Tables of simplified images of male heads and tails as well as list of important morphometric values are proposed as a tool for quicker identification of Anoplostoma species.
\end{abstract}

KEY WORDS: Anoplostoma, free-living nematodes, mangroves, taxonomy, Vietnam.

\section{Описание Anoplostoma nhatrangensis sp.n. из мангрового биотопа Нячанга, Центральный Вьетнам с таксономическим обзором рода Anoplostoma Bütschli, 1874 (Nematoda: Enoplida)}

\section{А.В. Чесунов ${ }^{1}$, Нгуен Ву Тхань 2}

\footnotetext{
${ }^{1}$ Кафедра зоологии беспозвоночных, Биологический факультет, Московский государственный университет, Москва 119991, Россия.

email: AVTchesunov@yandex.ru

${ }^{2}$ Институт Экологии и биоресурсов, Вьетнамская академия наук и технологий, 10000 Ханой, Вьетнам.
} 
PЕЗЮМЕ: Anoplostoma nhatrangensis sp.n. обнаружена в деградирующем мангровом биотопе в районе Нячанга, Центральный Вьетнам. Новый вид характеризуется относительно длинными внешними губными щетинками (o.1.s. 6,5-9 $\mu \mathrm{m}$ или 81$120 \%$ c.b.d.); относительно длинным хвостом с относительно большой задней тонкой цилиндрической частью (с 5,71-6,92, c' 8,96-11,8, dist.tail part 63-90\%); наличием у самцов только одной пары маленьких постанальных папилл и пары заднебурсальных латеральных щетинок (шипов) при отсутствии преанальных бурсальных сенсилл. $A$. nhatrangensis sp.n. наиболее сходен с A. heterurum, от которой отличается некоторыми морфометрическими параметрами: более толстым телом (а 33-45 против 56) и относительно более длинным хвостом (с 5,9-6,6 против 11 and c' 10-12 против 6,5) с относительно большей задней цилиндрической частью (82-90 против 75\%). Предлагается краткий таксономический обзор видов Anoplostoma. В составе рода двадцать номинальных видов, из них четырнадцать признаны валидными. В настоящей работе A. brevispiculum квалифицируется как вид incertae sedis, поскольку его признаки не соответствуют диагнозу рода; $A$. demani обозначен как species inquirenda по причине неполноты оригинального описания; A. macrospiculum признаётся младшим синонимом A. sunderbanae. Для ускоренной идентификации видов сконструирован пикториальный ключ, состоящий из двух компонентов, упрощённых образов голов и хвостов самцов, и таблицы важнейших морфометрических характеристик.

КЛЮЧЕВЫЕ СЛОВА: Anoplostoma, Вьетнам, мангровые биотопы, морские свободноживущие нематоды, таксономия.

\section{Introduction}

The present report is the first of a series of papers on free-living nematodes of mangrove habitats in the Nha Trang area, Khanh Hoa Province, Central Vietnam. In this area, mangroves are disappearing rapidly and the small remaining mangrove stands show various levels of degradation. Our goal is to understand diversity and communities of free-living nematodes under various conditions of normal, vanishing and restored mangroves.

A bulk of nematode species found in the Nha Trang mangroves are new for science. Here we describe a new species belonging to Anoplosto$m a$, a genus that includes many common intertidal or shelf species from various parts of world. We also present an annotated list of twenty nominal species and simplified figures of valid species together with their important morphometric diagnostic characters to facilitate identification of Anoplostoma species.

The first Anoplostoma species was described under the name Symplocostoma viviparum by
Bastian (1865); the genus Anoplostoma was established for this species by Bütschli (1874). Anoplostoma viviparum is the species most often reported, especially in the European seas. The genus Anoplostoma has been placed in the family Oncholaimidae Filipjev, 1916 on the basis of its very large buccal cavity with parallel sclerotized walls (e.g. Kreis, 1934). Gerlach and Riemann (1974) erected the new family Anoplostomatidae for the genus Anoplostoma. Later, the family Anoplostomatidae was supported by decisions of Belogurov and Alekseyev (1977) and by Lorenzen (1981). The latter author included the second genus Chaetonema in Anoplostomatidae. Morphological analysis (Lorenzen, 1981) as well as some molecular data (Pegova et al., 2004) both indicate a relation of Anoplostoma to the superfamily Enoploidea within the order Enoplida.

\section{Material and methods}

Samples of sediments were collected by a cylinder of $3 \mathrm{~cm}^{2}$ area during the low tide and 
fixed in situ with $4 \%$ formaldehyde solution on sea water. The meiofauna stained by Bengal rosa was isolated by decantation and filtration through a sieve of $70 \mu \mathrm{m}$ mesh size. The nematodes were extracted and put into watch glasses with Seinhorst's solution I (ethanol-glycerinwater mixture in proportion 29:1:70) and the ethanol and water were allowed to evaporate slowly. Specimens were mounted into permanent glycerin slides with a paraffin ring, glass bead separators and Glyceel seals. These slides were then studied with an Olympus BX51 light microscope equipped with Nomarski optics. All measurements are in $\mu \mathrm{m}$.

Abbreviations: a - body length divided by maximum body diameter; am.w. - width of the amphideal fovea, in $\mu \mathrm{m}$; am.w., $\%$ — width of the amphideal fovea, expressed as a percentage of the corresponding body diameter; $b$ - body length divided by pharyngeal length; burs.al.1. length of bursal alae, in $\mu \mathrm{m}$; c - body length divided by tail length; c' - tail length, expressed in anal diameters; calc* (calculated) morphometric value calculated from drawings of published species descriptions; c.b.d. - corresponding body diameter; c.s. - length of cephalic setae, in $\mu \mathrm{m}$; diam.am. — body diameter at the level of amphids, in $\mu \mathrm{m}$; diam.ani anal body diameter, in $\mu \mathrm{m}$; diam.ca. - body diameter at the level of cardia, in $\mu \mathrm{m}$; diam.c.s. body diameter at the level of cephalic setae, in $\mu \mathrm{m}$; diam.midb. - midbody diameter, in $\mu \mathrm{m}$; diam.n.r. — body diameter at the level of nerve ring, in $\mu \mathrm{m}$; dis.am. - distance from the cephalic apex to the anterior margin of the amphideal fovea, in $\mu \mathrm{m}$; d.tail p., $\%$ - length of posterior cylindrical tail portion, expressed as a percentage of the entire tail; gub.l. - length of gubernaculum along the spiculum, in $\mu \mathrm{m} ; \mathrm{L}$ - body length, in $\mu \mathrm{m}$; o.l.s. - length of outer labial setae, in $\mu \mathrm{m}$; o.l.s., $\%$ - length of outer labial setae, expressed as a percentage of the corresponding body diameter; spic.arc — spicule's length along the arch, in $\mu \mathrm{m}$; spic.chord -spicule's length along the chord, in $\mu \mathrm{m}$; st.l. total stoma length, in $\mu \mathrm{m}$; st.w. - maximal stoma width, in $\mu \mathrm{m} ; \mathrm{V}, \%$ - distance of vulva from anterior end as percentage of body length.
Anoplostomatidae Gerlach et Riemann, 1974

Anoplostoma Bütschli, 1874

Anoplostomatidae. Body elongate spindleshaped. Cuticle smooth. Triangular mouth opening surrounded by six inner labial papillae. Six longer outer labial setae and four cephalic setae form two circles very close one after another. Amphideal fovea equal in males and females, ovoid pocket-shaped with a small anterior aperture, situated posterior to the buccal cavity. Cephalic capsule formed by three longitudinal elements (muniments of Belogurov, Alekseyev, 1977) presenting sclerotized differentiations in the inner layer of the somatic perioral cuticle. Buccal cavity voluminous and toothless, formed by parallel sclerotized walls free of muscular tissue (gymnostom). Pharynx muscular throughout its length. Outlets of pharyngeal glands just posterior to the buccal cavity. Ventral pore known in a few species situated well behind buccal cavity. Two testes, anterior outstretched and posterior reflexed. Two antidromously reflexed ovaries. Males provided with paired bursal alae bearing posterior lateral spines and possibly small other papillae. Tail consists of anterior conical portion and posterior slender cylindrical flagellum.

Type species Sympocostoma viviparum Bastian, 1865. Chaetonema Filipjev, 1927, the only other genus of Anoplostomatidae differs from Anoplostoma by extreme sexual dimorphism in construction of amphids, presence of Steiner's organ - a structure of unknown function in the vicinity of the amphids, and absence of bursal alae in males.

\section{Remarks to taxonomy and identi- fication of Anoplostoma species}

Species of Anoplostoma mostly are structurally very similar to one another and hence measurements are important. Apparently the main characters permitting species identification are length of the outer labial setae and tail length expressed as ratios $\mathrm{c}$ and $\mathrm{c}^{\prime}$. The species on figs 1 and 2 are arranged in a row of successive obvious decrease of the tail expressed in c'. 

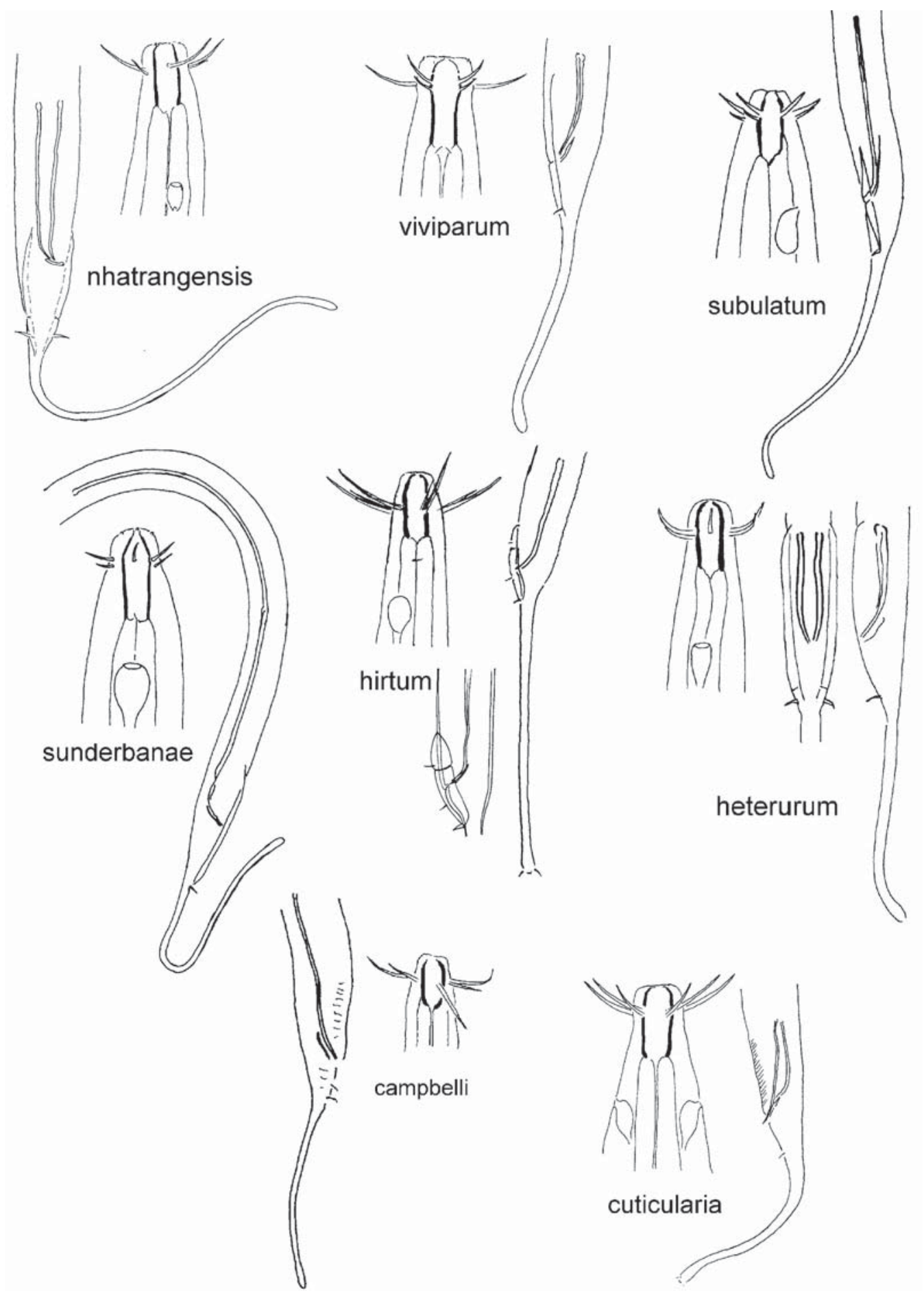

Fig. 1. Pictorial key for valid species of Anoplostoma. Part 1.

Рис. 1. Пикториальный ключ к определению валидных видов Anoplostoma. Часть 1. 

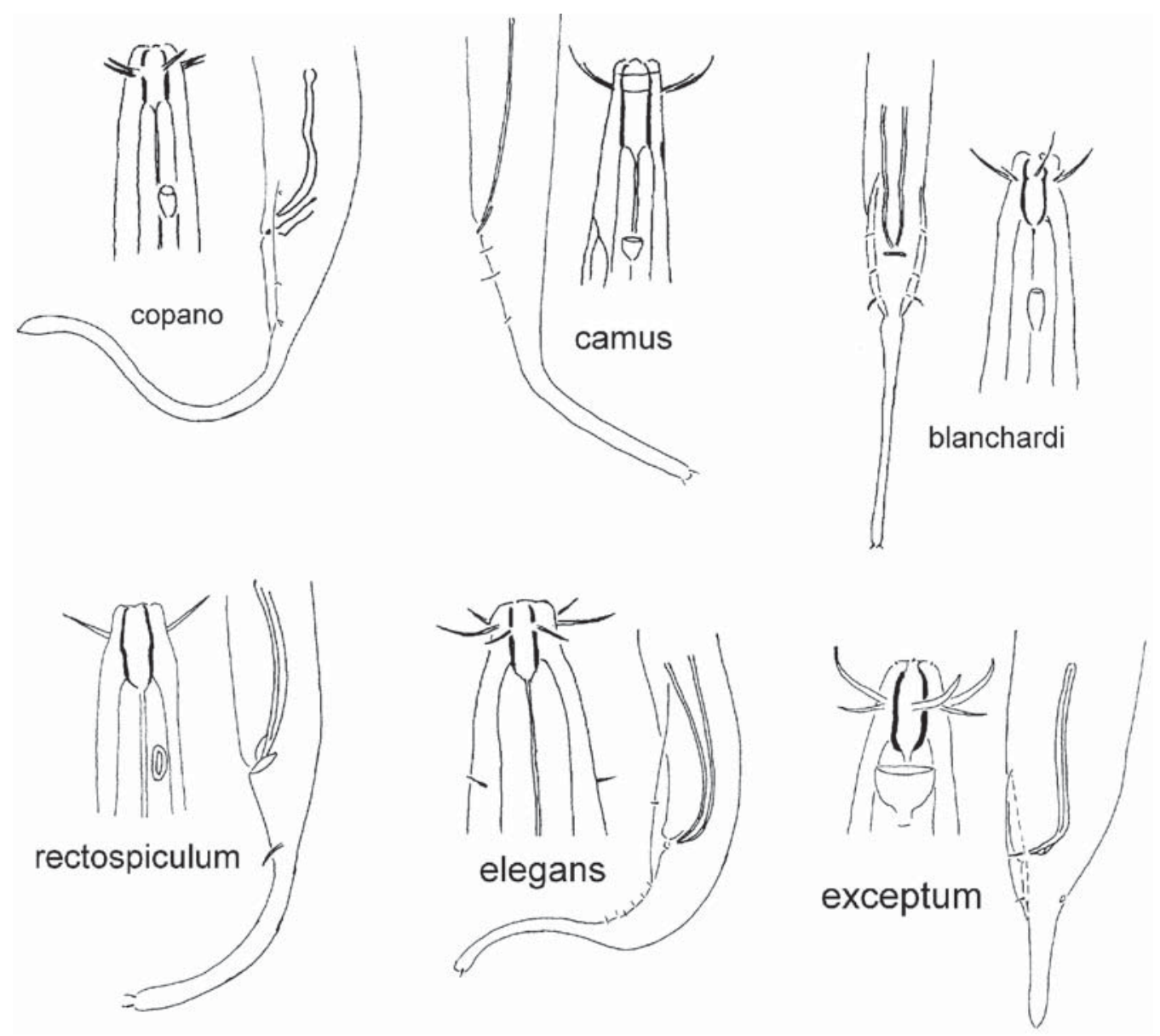

Рис. 2. Pictorial key for valid species of Anoplostoma. Part 2.

Fig. 2. Пикториальный ключ к определению валидных видов Anoplostoma. Часть 2.

Males are more easily identified than females because they possess informative sexual structures as spicules, showing species specific differences in shape and length, and bursal alae with sensilla differing in number and arrangement according to the species. For example, $A$. sunderbanae is easily distinguished by its very long spicules, and number and position of bursal papillae. Females also may express species specific differences in reproductive branches, e.g. spermatheca can be present as shown by Rachor (1969) in figs 26, 27. Females of A. viviparum may be distinguished by their viviparity that is unknown or at least not evident in other species.
Table 1 summarizes the most important diagnostic characters for species identification of males of valid Anoplostoma species. Simplified images of male heads and tails presented in figures (Figs 1 and 2) may also serve as a tool for identification of Anoplostoma species. Images are modified from the following sources presenting the best published figures, mostly from original diagnoses: A. blanchardi from Hopper (1969); A. campbelli from Allgén (1932); A. camus from Wieser (1953); A. copano from Chitwood (1951); A. cuticularia from Belogurov, Alekseyev (1977); A. elegans from Kreis (1929); A. exceptum from Gerlach (1953); 
Table 1. Diagnostic morphometric characters of males of valid Anoplostoma species.

Таблица 1. Отличительные морфометрические характеристики валидных видов Anoplostoma.

\begin{tabular}{|l|c|c|c|c|c|c|c|}
\hline \multirow{2}{*}{ Species } & \multicolumn{9}{|c|}{ Characters } \\
\cline { 2 - 8 } & $\mathbf{L}$ & $\mathbf{a}$ & $\mathbf{c}$ & $\mathbf{0 . 1 . s . ,} \%$ & $\mathbf{s p i c . , ~} \boldsymbol{\mu m}$ & c' & d.tail p., \% \\
\hline A. blanchardi & $1080-1250$ & 35 & $11-15$ & $83-110^{*}$ & 50 & $4.6^{*}$ & $72^{*}$ \\
\hline A. campbelli & 1650 & 37 & 11 & $138-144^{*}$ & 140 & $6.1^{*}$ & $85^{*}$ \\
\hline A. camus & $1180-1520$ & $22-37$ & $13-14$ & $129^{*}$ & 65 & $4-5$ & $56^{*}$ \\
\hline A. copano & 1120 & 28 & 6.2 & 100 & 48 & $5.8^{*}$ & $78^{*}$ \\
\hline A. cuticularia & $1190-1420$ & $27-39$ & $8-9.5$ & $132^{*}$ & $61-68$ & $5-6$ & $80^{*}$ \\
\hline A. elegans & $2602-2880$ & $47-48$ & $12-16$ & 100 & $145-190$ & $4-4.5$ & 60 \\
\hline A. exceptum & $943-1144$ & $21-29$ & $11-17$ & $100-113^{*}$ & $66-70$ & $4-4.5^{*}$ & $81-84^{*}$ \\
\hline A. heterurum & 1200 & $56^{*}$ & $11^{*}$ & 100 & $?$ & $6.5^{*}$ & $75^{*}$ \\
\hline A. hirtum & $1250-1560$ & $46-47$ & $8.3-12.5$ & $207-208^{*}$ & $65-67$ & $6-8.2^{*}$ & $89-94^{*}$ \\
\hline A. nhatrangensis & $1091-1159$ & $33-45$ & $5.9-6.6$ & $107-120$ & $46-56$ & $10-12$ & $82-90$ \\
\hline A. rectospiculum & $1496-1837$ & $30-41$ & $11-14$ & $88^{*}$ & $54-60$ & 4.5 & 75 \\
\hline A. subulatum & 1462 & 42 & 8 & $75^{*}$ & $86-101$ & $7.3-9^{*}$ & $83^{*}$ \\
\hline A. sunderbanae & $1090-1250$ & $43-62$ & $8-10$ & $100\left(60^{*}\right)$ & inequal, $96-$ & $6.5-9$ & 80 \\
\hline A. viviparum & $1600-2100$ & $33-45$ & $6.3-12$ & $80-100$ & $40-65$ & $4.3-9.2$ & 74 \\
\hline
\end{tabular}

The morphometric data are summarized from illustrations and descriptions cited in the "Annotated list of species" above. * means the data were calculated from published pictures.

A. heterurum from Cobb (1914); A. hirtum from Gerlach (1956); A. nhatrangensis — original; A. rectospiculum from Galtsova (1976); $A$. subulatum from Gerlach (1957b); A. sunderbanae from Timm (1967); A. viviparum from de Man (1907).

\section{Annotated list of Anoplostoma species}

1. Anoplostoma blanchardi de Man, 1888. See De Man (1888): 18-19, fig. 10-10c (North Sea); Hopper(1969): 673, fig. 4-6(Nova Scotia, Atlantic coast of Canada). Both illustrated descriptions cited agree with one another in details. The species was also briefly recorded by other authors in the North Sea and in western part of the Baltic Sea (Gerlach, Riemann, 1974).

2. Anoplostoma brevispiculum Sergeeva, 1974. See Sergeeva (1974): 123, figs 7 a, b (Black Sea). The original description and figures are poor and miss important details. Further, the original description includes structures that are not characteristic of the genus, such as the absence of anterior setae, position of the amphideal fovea at stoma base, short spicules, absence of bursal alae.

3. Anoplostoma campbelli Allgén, 1932. See Allgén (1928): 274-275 (Campbell Island, as $A$. blanchardi, opinion of De Coninck and Stekhoven, 1933: 57); Allgén (1932): 117-119, figs 13 a-d (Campbell Island, Pacific). The original description is based upon a single male specimen and a juvenile and lacks some measurements such as stoma length, distance from the apex to the amphideal fovea, length of the bursal alae. However, the species clearly differs from congeners by exceptionally long anterior setae and spicules. The identification of specimens from Macquarie Island as $A$. campbelli by Mawson (1958: 354, fig. 39 a-e) appears questionable because of their: 1) shorter outer labial setae (107 versus $150 \%$ c.b.d., both calculated from figures) and 2) shorter spicules (78 versus $140 \mu \mathrm{m})$ though their relative length in anal diameters and tail lengths are similar. The specimens recorded by Gerlach (1955: 261-262, no figures) from San Salvador also do not fit well to the original diagnosis of Allgén because of shorter spicules $(62-90 \mu \mathrm{m})$.

4. Anoplostoma camus Wieser, 1953. See Wieser (1953): 103-104, fig. 61 a-c (Chile). Males are differentiated based on presence of three pairs of postanal setose sensilla, one pair of small papillae lateroventral spines, inconspicuous bursal alae, and probably by presence of a thin transversal ring in the buccal cavity. 
5. Anoplostoma copano Chitwood, 1951. See Chitwood (1951): 626-627, figs $1 \mathrm{G}-\mathrm{H}$ (Gulf of Mexico). Original diagnosis is very brief but the figures are clear. Three pairs of genital papillae are indicated.

6. A. cuticularia Belogurov et Alekseyev, 1977. See Belogurov and Alekseyev (1977): 188-191, figs 1-3 (Sea of Japan). The species is similar to A. viviparum but differs by longer outer labial setae and oviparity. The authors described so called muniments which are possibly less distinct in other Anoplostoma species. The muniments are two subdorsal and one midventral sclerotized $\mathrm{H}$-shaped structures inserted into inner layer of the somatic cuticle at the level of outer labial and cephalic setae.

7. Anoplostoma demani Timm, 1952. See Timm (1952): 11, fig. 9 (Chesapeak Bay, east coast of USA). Original diagnosis is based on one female specimen. The description is very brief and contains some questionable details such as only six setae on the anterior end. We assume here $A$. demani as species inquirenda.

8. Anoplostoma dubium Allgén, 1959. See Allgén (1959): 78, fig. 71 a-c (Antarctica). The species has been designated as species inquiren$d a$ by Chitwood (1960: 357).

9. Anoplostoma elegans Kreis, 1929. See Kreis (1929): 37-39, fig. 10 a-c (English Channel). The species differs well from other Anoplostoma species by greater size of the body and organs, and a row of several postanal setae posterior to bursa on the conical part of the tail. An amphideal fovea is not depicted on the original figure, but its position is indicated as four cephalic diameters posterior to the apex.

10. Anoplostoma exceptum Schulz, 1935. See Schulz (1935): 440-442, Abb. 5-7 (Kiel Bay); Gerlach (1952): 323, 350, fig. Abb. $19 \mathrm{a}-\mathrm{b}$ (Kiel Bay, Mediterranean); Gerlach (1953): 538539, Abb. 10 (Mediterranean); Blome (1982): 440-442, Abb. 34 E-G (North Sea). All descriptions agree with one another in detail. The species is easy identified because of its amphideal fovea situated close to the buccal cavity and short tail comparable with spicule's length.

11. Anoplostoma heterurum (Cobb, 1914). See Cobb (1914): 100-102, fig. 21 I-IV (Flor- ida, fresh water pond, as Oncholaimellus heterurus, opinion of Kreis, 1934: 107). The species should be redescribed since the original description is tediously long and lacks some important dimensions. The habitat indicated by Cobb is unusual for Anoplostoma.

12. Anoplostoma hirtum Gerlach, 1956. See Gerlach (1956): 12, Abb. 6 a-d (Brazil); Gerlach (1958): 354-356, fig. 6 a-c (Madagascar). Gerlach (1958) designated the male specimen from Madagascar as „,f. hirtum” because of some dissimilar shape and slightly shorter bursal alae. We could not find any significant differences between both descriptions and hence assume Brazil and Madagascar specimens as conspecific.

13. Anoplostoma macrospiculum Sinha, Choudhury and Baqri, 1987. See Sinha et al. (1987): 539-540, fig. 1 (West Bengal). See Anoplostoma sunderbanae.

\section{Anoplostoma nhatrangensis sp.n.}

15. Anoplostoma rectospiculum Galtsova, 1976. See Galtsova (1976): 200, fig. 9 (White Sea, intertidal zone, North Russia). Validity of the species needs to be reconsidered because of its overall resemblance to A. viviparum. Bursal alae and their sensilla are not properly described in the original diagnosis, and its mode of reproduction (oviparity or viviparity) is not indicated in the original description.

16. Anoplostoma subulatum Gerlach, 1957. See Gerlach (1957): 138-140, Abb. 2 d-h (Brazil, mangroves). The species is characterized by somewhat shorter outer labial setae, weak bursal alae with papillae just anterior to the cloacal opening and long slender spicules.

17. Anoplostoma sunderbanae Timm, 1967. See Timm (1967): 1-2, 1 A-C (Bay of Bengal, Gulf of Thailand). The species is distinguished by extremely long and unequal spicules. At present, the only other species described with spicules very similar in shape and size is A. macrospiculum Sinha, Choudhury and Baqri 1987. The original description of $\mathrm{A}$. $\mathrm{mac}$ rospiculum is incomplete, particularly lacking data on body length and de Man's indices. A few measurements cited by Sinha et al. for A. macrospiculum such as stoma length and c' coincide 
well with those of $A$. sunderbanae. The only feature which could be treated as a specific difference is terminal setae on the tail tip present on $A$. macrospiculum but not mentioned by Timm for $A$. sunderbanae. These setae could have been overlooked in the original diagnosis of $A$. sunderbanae. Here we consider both species conspecific and the name macrospiculum as a junior synonym of sunderbanae.

18. Anoplostoma tenuicaudum Allgén, 1959. See Allgén (1959): 80, fig. 73 a-b (Subantarctica, Falkland Islands). The species was described on insufficient material (only one juvenile specimen) and thus has been considered as species inquirenda by Chitwood (1960).

19. Anoplostoma tenuisetum Allgén, 1959. See Allgén (1959): 78-80, fig. 72 a-b (Subantarctica, South Georgia). Chitwood (1960) suggested this species may be conspecific with $A$. campbelli. Since this species was described on insufficient material (only two females and a juvenile) we consider A. tenuisetum as species inquirenda.

20. Anoplostoma viviparum (Bastian, 1865). The species is widely registered around the world; all findings and synonyms until 1973 were compiled by Gerlach and Riemann (1974). The findings reveal that the species is very abundant along the northern European coast where it is quite common especially in the intertidal zone but also occurs in brackish waters (English Channel, around the Britain and Ireland, North Sea, Baltic Sea, Norway Sea). The species was also repeatedly recorded in southern Europe, i.e. Mediterranean, Black Sea, Azov Sea and recently in the Caspian Sea (observation of first author). Further records were made in Atlantic coasts (Congo, Chesapeake Bay, Florida, Brazil) and along the Pacific coast of northern California. Some of the records have more or less detailed measurements and descriptions showing some differences among specimens of diverse localities. Apart from morphometric differences, the specimens may or may not have minute preanal bursal papillae (e.g. Platt, Warwick, 1973; Chitwood, 1960 versus Bütschli, 1874; Schneider, 1906; de Man, 1907; Stekhoven, 1942; Timm, 1952; Gerlach, 1957a, 1957b). Considering these minute structures may have been missed in earlier works, we assume the preanal bursal sensilla as characteristic of $A$. viviparum. Another significant diagnostic feature mentioned in almost all description is viviparity of this species.

\section{Anoplostoma nhatrangensis sp.n.}

Figs 3-4, Table 2.

TYPE MATERIAL. Holotype male, three paratype males, seven paratype females in slides deposited in the nematode collection of Department of Nematology, Institute of Ecology and Biological Resources (IEBR), Vietnam Academy of Science and Technology, 18 Hoang Quoc Viet Rd., 10000 Hanoi, Vietnam.

TYPE LOCALITY. Central Vietnam coast, Khanh Hoa Province, south of Nha Trang City, Be estuary $\left(12^{\circ} 23.033^{\prime} \mathrm{N}, 109^{\circ} 10.899^{\prime} \mathrm{E}\right)$, intertidal mangrove zone, silty sand, areas of burrows of the crabs Uca spp. and roots of Rhizophora mangrove trees. Collected 16.03. 2008.

DESCRIPTION. Body elongate, spindleshaped. Cuticle smooth. Anterior part of the head in front of the crown of setae separated with a slight but distinct constriction. Six nonprominent inner labial papillae arranged apically around the mouth. Anterior crown of sensilla made up of six long outer labial setae and four much shorter cephalic setae. Setae of both circles smooth (not segmented). Cephalic setae situated in slightly more lateral and posterior position in relation to outer labial setae.

No cervical or somatic setae visible. Loxometanemes present over lateral fields.

Amphideal foveas well posterior to the lip region, pocket-shaped, ellipsoid in outline, with small transversally-ovoid anterior aperture, and ciliary processes discernible in corpus gelatum. Small mucus protuberances often emerge from the amphideal apertures.

Buccal cavity voluminous, cylindroid. Cheilostoma counter-cup-shaped, with sclerotized cheilorhabdions. Three sclerotized structures (muniments) inserted in the inner layer of the endocupola well visible at the level of anterior third of gymnostoma. Gymnostoma made up of parallel sclerotized gymnorhabdions. Stegostoma surrounded with the pharyngeal tis- 


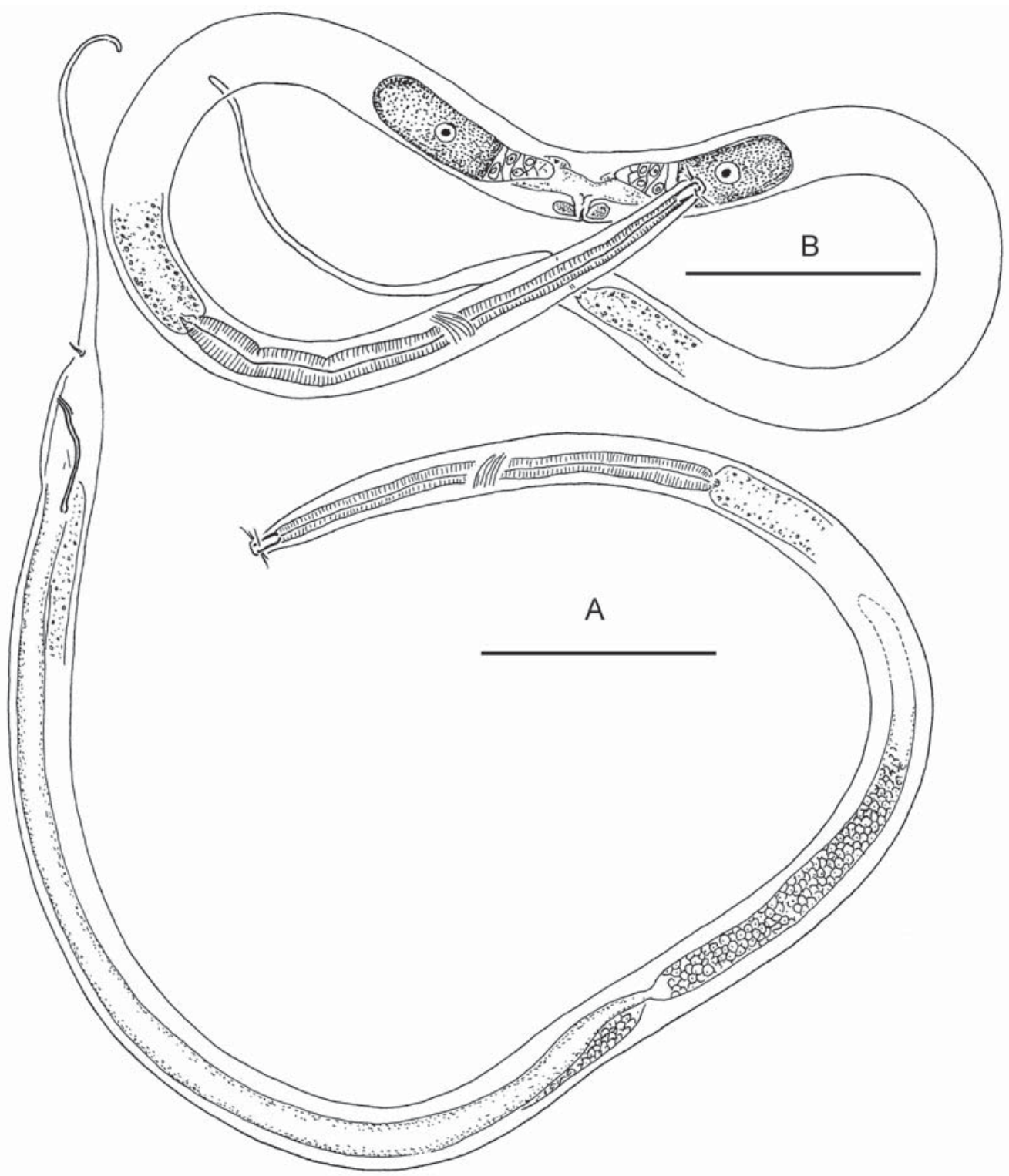

Fig. 3. Anoplostoma nhatrangensis sp.n., entire.

A - holotype male N1; B - paratype female. Scale bars: $100 \mu \mathrm{m}$.

Рис. 3. Anoplostoma nhatrangensis sp.n., общий вид.

A - самец N1 (голотип); B - самка (паратип). Масштаб: 100 мкм.

sue cuff reduced to the stoma bottom where also some granular sclerotizations present.

Pharynx cylindroid, gradually broadened to the cardia, evenly muscular. Cardia small, triangular, inserted into the intestinal tissue.
Intestine may contain scarce coarse particulate material.

Ventral pore only discernible in one female where situated at a distance $57 \mu \mathrm{m}$ from the anterior end. No indication of renette cell. 

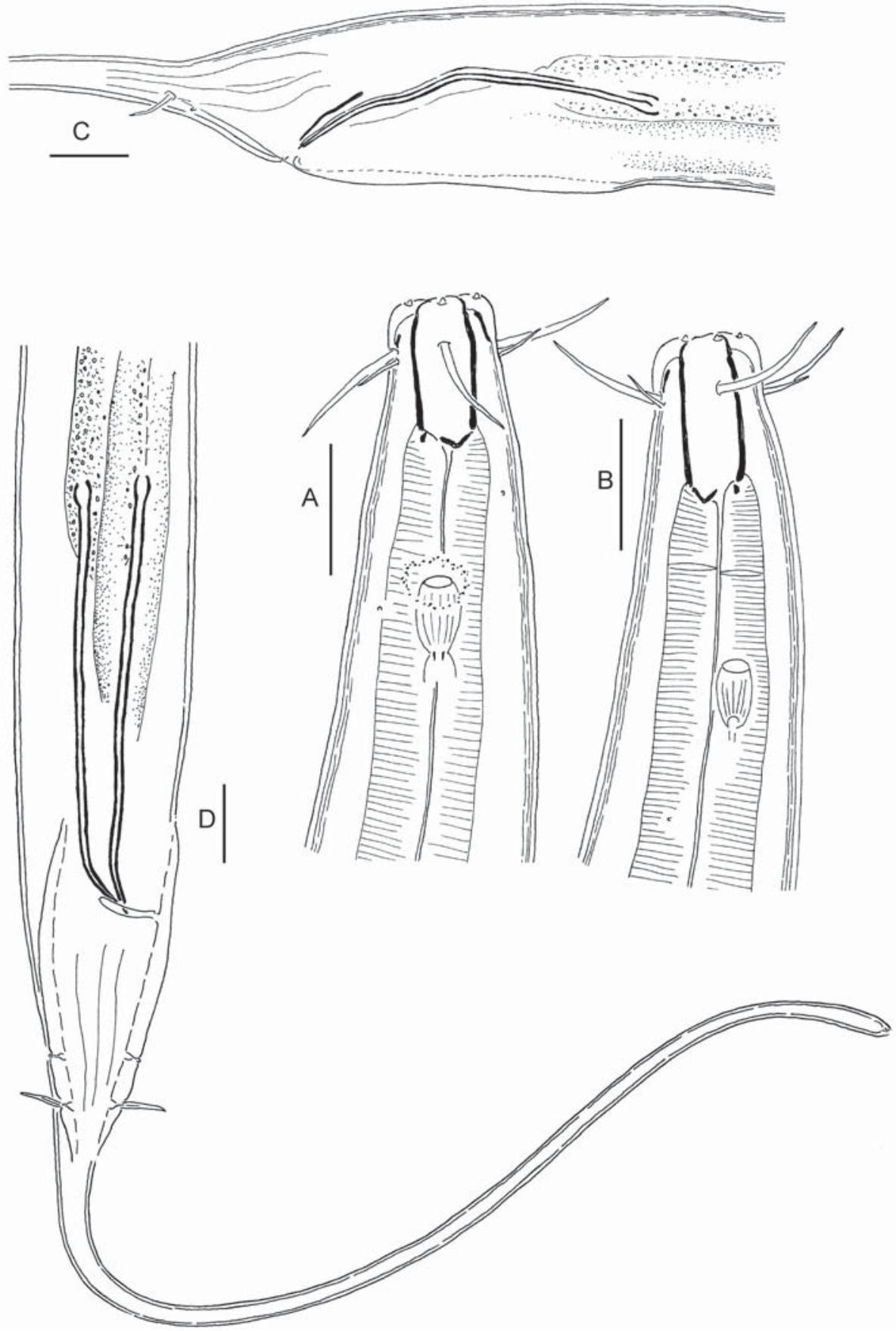

Fig. 4. Anoplostoma nhatrangensis sp.n., details.

A - anterior end of the holotype male; B - anterior end of the paratype female; C - posterior body of the paratype male; D - pericloacal body region of the holotype male; oblique ventral orientation. Scale bars: $10 \mu \mathrm{m}$.

Рис. 4. Anoplostoma nhatrangensis sp.n., детали.

А - головной конец самца (голотип); В - головной конец самки (паратип); С - задняя часть тела самца (паратип); D - околоанальная область самца (голотип); латеровентральная ориентация. Масштаб: 10 мкм. 
Table 2 . Morphometrics of Anoplostoma nhatrangensis sp.n. Таблица 2. Морфометрия Anoplostoma nhatrangensis sp.n.

\begin{tabular}{|l|c|c|c|c|c|}
\hline \multirow{2}{*}{ Character } & \multirow{2}{*}{$\mathrm{O}^{\top}$ holotype } & \multicolumn{2}{|c|}{ Males (n=4) } & \multicolumn{2}{c|}{ Females (n=7) } \\
\cline { 3 - 6 } & & min-max & mean \pm SD & min-max & mean \pm SD \\
\hline L & 1159 & $1091-1159$ & $1124 \pm 29.9$ & $969-1255$ & $1154 \pm 99.8$ \\
\hline A & 44.6 & $33.1-44.6$ & $36.4 \pm 5.48$ & $29.4-38.7$ & $35 \pm 3.33$ \\
\hline B & 5.8 & $4.81-5.92$ & $5.4 \pm 0.59$ & $4.43-5.6$ & $4.88 \pm 0.38$ \\
\hline C & 6.18 & $5.92-6.92$ & $6.39 \pm 0.44$ & $5.71-6.37$ & $6.06 \pm 0.26$ \\
\hline V.\% & - & - & - & $44.6-47.6$ & $45.9 \pm 1.04$ \\
\hline diam.c.s. & 7.5 & $7-7.5$ & $7.38 \pm 0.25$ & $6.5-8$ & $7.5 \pm 0.58$ \\
\hline diam.am. & 15 & $12.5-15$ & $13.3 \pm 1.19$ & $12.5-14.5$ & $13.5 \pm 0.71$ \\
\hline diam.n.r. & 23 & $23-27$ & $24.8 \pm 1.71$ & $23.5-26$ & $24.9 \pm 0.86$ \\
\hline diam.ca. & 25 & $25-32$ & $28.5 \pm 3.11$ & $26-31$ & $29.3 \pm 1.73$ \\
\hline diam.midb. & 26 & $26-33$ & $31.3 \pm 3.5$ & $29-38$ & $33.1 \pm 3.24$ \\
\hline diam.ani & 17 & $15.5-17$ & $16.1 \pm 0.63$ & $16-19$ & $17.4 \pm 1.02$ \\
\hline o.1.s. & 8.7 & $8-8.7$ & $8.3 \pm 0.36$ & $6.5-9$ & $7.43 \pm 0.93$ \\
\hline o.1.s., \% & 116.5 & $107-117$ & $113 \pm 4.03$ & $81-120$ & $99.4 \pm 12.6$ \\
\hline c.s. & 3.25 & $3.25-4$ & $3.56 \pm 0.31$ & $2-4$ & $3.14 \pm 0.63$ \\
\hline am.w. & 3.5 & $3.5-4$ & $3.75 \pm 0.29$ & $3-3.5$ & $3.21 \pm 0.27$ \\
\hline am.w., \% & 23.3 & $23.3-32$ & $28.6 \pm 3.91$ & $21.5-28$ & $23.8 \pm 2.17$ \\
\hline dis.am. & 20.5 & $20.5-25$ & $27.3 \pm 1.97$ & $22-27$ & $25 \pm 1.73$ \\
\hline st.w. & 4.5 & $4-5$ & $4.5 \pm 0.41$ & $3.5-5$ & $4.21 \pm 0.49$ \\
\hline st.1. & 11 & $10-11$ & $10.8 \pm 0.5$ & $9.5-11.5$ & $10.6 \pm 0.69$ \\
\hline burs.al.1. & 37 & $23-40$ & $37.3 \pm 2.52$ & - & - \\
\hline spic.chord & 46 & $46-56$ & $52.8 \pm 4.57$ & - & - \\
\hline spic.arc & 49 & $49-57$ & $54 \pm 4.36$ & - & - \\
\hline gub.1. & 9 & $7-9$ & $8 \pm 1$ & - & - \\
\hline c' & 10 & $9.16-11.8$ & $10.5 \pm 1.15$ & $8.96-11.8$ & $10.6 \pm 1.14$ \\
\hline d.tail p., \% & 90 & $82-90$ & $85.6 \pm 3.63$ & $63-80$ & $73.8 \pm 5.52$ \\
\hline
\end{tabular}

Female reproductive system didelphic-amphidelphic, ovaries antidromously reflexed, both to the left of the intestine in all females. No spermathecae present; no spermatozoa found in uteri. Vagina short, perpendicular to the longitudinal body axis. Vulvar glands present anterior and posterior to the vagina.

Male diorchic; both testes and vas deferens located left of the intestine. Spicules long and slender, slightly ventrally curved in distal third; distal ends pointed, proximal ends very weakly knob-like cephalated. Gubernaculum paired, as uncertain bar along distal quarter of spicule. Bursal alae variable in length, extending from conical part of tail to mid-level or proximal end of retracted spicules. Paired lateroventral spinelike setae $5 \mu \mathrm{m}$ long located on posterior end of bursal alae. A minute papilla on the ala just anterior to the each lateroventral spine.
Tail conical anteriorly and filiform posteriorly with slightly swollen tip and terminal spinneret. Caudal gland cell bodies protruded anteriorly into preanal region. No terminal setae found possibly except for one female with very minute terminal setae hardly visible.

DIAGNOSIS. Anoplostoma nhatrangensis sp.n. characterized by relatively long outer labial setae (o.1.s. $6.5-9 \mu \mathrm{m}$ or $81-120 \%$ c.b.d.); relatively long tail with longer posterior filiform portion (c 5.71-6.92, c' 8.96-11.8, d.tail p. 6390\%); males without preanal bursal papillae apart from a minute postanal bursal papilla just anterior to the posterior bursal spine.

DIFFERENTIAL DIAGNOSIS. Anoplostoma nhatrangensis sp.n. is most similar to the A. heterurum having no obvious structural differences. However, the morphometric values between two species show distinct gapes: $A$. 
nhatrangensis sp.n. versus A. heterurum has a stouter body (a 33-45 versus 56), and relatively longer tail (c 5.9-6.6 versus 11 and c' 10-12 versus 6.5 ) with greater posterior slender cylindrical portion (82-90 versus 75\%).

ECOLOGICAL REMARK. Anoplostoma nhatrangensis is very abundant in the site with roots of the mangrove tree Rhizophora stylosa (the third abundant species there) but also presents in lesser number in two other sites - in the site of pneumatophore roots of the mangrove tree Avicennia aff. alba and in the site with burrows of brachyuran crabs Uca sp. No females with ripe eggs in uteri were found in April-May 2008.

\section{Acknowledgements}

The project has been financed by RussianVietnamese Tropical Center for Science and Technology and partly by Russian Ministry of Education and Science (grants \#\# 02.740. 11.0280, \# П1291) and by Grant Council of the President of Russia (grant 4456.2010.4). We are grateful to two anonymous reviewers and editors for constructive criticism and improvement of the manuscript.

\section{References}

Allgén C. 1928. Freilebende marine Nematoden von den Campbell- und Staateninseln // Nyt Magazin for Naturvidenskaberne. Bd.66. S.249-309.

Allgén C. 1932. Weitere Beiträge zur Kenntnis der marinen Nematodenfauna der Campbellinsel // Nyt Magazin for Naturvidenskaberne. Bd.70. S.97-198.

Allgén C. 1959. Freeliving marine nematodes // Further zoological Results of the Swedish Antarctic Expedition. Bd.5. S.1-293.

Bastian H.C. 1865. Monograph on the Anguillulidae, or free nematoids, marine, land, and freshwater; with descriptions of 100 new species // Transactions of the Linnean Society of London. Vol.25. P.73-184.

Blome D. 1982. Systematik der Nematoda eines Sandstrandes der Nordseeinsel Sylt // Mikrofauna des Meeresbodens. Bd.86. S.1-194.

Belogurov O.I., Alekseyev V.M. 1977. [Morphology of Anoplostoma cuticularia sp.n. (Nematoda, Enoplida) and status of the family Anoplostomatidae Gerlach et Riemann, 1974 in the system of nematodes] // Zoologicheskii Zhurnal. T.56. P.188-198 [in Russian, with English summary].
Bütschli O. 1874. Zur Kenntnis der freilebenden Nematoden, insbesondere der des Kieler Hafens // Abhandlungen der Senckenbergischen Naturforschen Gesellschaft. Bd.9. S.236-292.

Chitwood B. G. 1951. North American marine nematodes // Texas Journal of Science. Vol.3. P.617-672.

Chitwood B.G. 1960. A preliminary contribution on the marine nemas (Adenophora) of Northern California // Transactions of the American Microscopical Society. Vol.79. P.347-384.

Cobb N.A. 1914. The North American free-living freshwater nematodes // Transactions of the American Microscopical Society. Vol.33. P.69-119 (reprinted in Contributions to a Science of Nematology (Baltimore), 2: 35-99).

De Coninck L.A., Schuurmans Stekhoven J.H. 1933. The free-living marine nemas of the Belgian coast II // Mémoires du Musée royal d'Histoire naturelle de Belgique. T.58. P.1-163

de Man J.G. 1888. Sur quelques Nématodes libres de la mer du Nord nouveaux ou peu connu // Mémoires de la Société Zoologique de France. T.1. P.1-51.

de Man J.G. 1907. Sur quelques especes nouvelles ou peu connues de Nématodes libres habitant les côtes de la Zélande // Mémoires de la Société Zoologique de France. T.20. P.33-90.

Galtsova V.V. 1976. [Free-living marine nematodes as a component of the meiobenthos of Chupa Inlet of the White Sea] // Issledovanija fauni morjei 17(25). Nematody i ikh Rol' v Meiobentose. P.165-272 [in Russian].

Gerlach S.A. 1952. Nematoden aus dem Küstengrundwasser // Akademie der Wissenschaften und Literatur, Mainz. Abhandlungen der mathemathik-naturwissenschaftlichen Klasse. Bd.6. S.315-372.

Gerlach S.A. 1953. Die Nematodenbesiedlung des Sandstrandes und des Küstengrundwassers an der italienischen Kuste. I. Systematischer Teil // Archivio Zoologico Italiano. Vol.37. P.517-640.

Gerlach S.A. 1955. Zur Kenntnis der freilebenden marinen Nematoden von San Salvador // Zeitschrift für wissenschaftliche Zoologie. Bd. 158. S.249-303.

Gerlach S.A. 1956. Brasilianische Meeres-Nematoden I // Boletim do Instituto Oceanográfico, São Paulo. Vol.5. P.3-69.

Gerlach S.A. 1957a. Marine Nematoden von der KongoMündung // Bulletin del'Institut Royal des Sciences Naturelles de Belgique, Biologie. Bd.33. S.1-16.

Gerlach S. A. 1957b. Marine Nematoden aus dem Mangrove-Gebiet von Cananéia (Brasilianische MeeresNematoden III) // Akademie der Wissenschaften und Literatur, Mainz. Abhandlungen der mathemathiknaturwissenschaftlichen Klasse. Bd.5. S.129-176.

Gerlach S.A. 1958. Deuxième contribution à la faune des Nématodes des eaux interstitielles littorales de Madagascar // Mémoires de'Institut scientifique de Madagascar (F). T.2. S.343-365.

Gerlach S.A., Riemann F.1974. The Bremerhaven checklist of aquatic nematodes. A catalogue of Nematoda Adenophorea excluding the Dorylaimida. Part $2 / /$ 
Veröffentlichungen des Instituts für Meeresforschung in Bremerhaven, Supplement 4, Heft 2. S.405-734.

Hopper B.E. 1969. Marine nematodes of Canada. II. Marine nematodes from the Minas Basin - Scots Bay area of the Bay of Fundy, Nova Scotia // Canadian Journal of Zoology. Vol.47. P.671-690.

Kreis Đ. 1929. Freilebende marine Nematoden von der Nordwestküste Frankreichs (Trébeurden Côtes du Nord) // Capita Zoologica. Bd.2. S.1-98.

Kreis H. 1934. Oncholaiminae Filipjev 1916. Eine monographische Studie // Capita Zoologica. Bd.4. S.1-271.

Lorenzen S. 1981. Entwurf eines phylogenetischen Systems der freilebenden Nematoden // Veröffentlichungen des Instituts für Meeresforschung in Bremerhaven, Supplement 7. 472 S.

Mawson P.M. 1958. Free-living nematodes section 3: Enoploidea from Subantarctic stations // Rep. B.A. N.Z. antarct. Res. Exped. (B). Vol.6. P.307-358.

Pegova A. N., Krasnova E.D., Aleshin V.V. 2004. Evidence from the small and large ribosomal RNA structure suggests that Anoplostoma rectospiculum Gal'tsova, 1976 (Nematoda: Anoplostomatidae) is member of the superfamily Enoploidea, not Oncholaimoidea // Nematology. Vol.6. P.413-421.

Platt H.M., Warwick R.M. 1983. Free-living marine nematodes. Part I. British Enoplids. Pictorial keys to world genera and notes for the identification of British species // Synopses of the British Fauna (New Series), 28. Published for the Linnean Society of London and the Estuarine and Brackish-Water Sciences Association. Cambridge University Press. Cambridge, London, New York, New Rochelle, Melbourne, Sydney. $307 \mathrm{p}$.
Rachor E. 1969. Das de Mansche Organ der Oncholaimidae, eine genito-intestinale Verbindung bei Nematoden // Zeitschrift für Morphologie und Ökologie der Tiere. Bd.66. S.87-166.

Schneider G. 1906. Beitrag zur Kenntnis der im Uferschlamm des Finnischen Meeresbusens freilebenden Nematoden // Acta Societatis pro Fauna et Flora Fennica. Vol.27. P.1-40.

Schulz E. 1935. Nematoden aus dem Küstengrundwasser // Schriften des Naturwissenschaftlichen Vereins für Schleswig-Holstein. Bd.20. S.435-467.

Sergeeva N.G. 1974. [New free living nematodes (Enoplida) from the Black Sea. 2] // Zoologicheskii Zhurnal. T.53. P.120-125 [in Russian, with English summary].

Sinha B., Choudhury A., Baqri Q.H. 1987. Studies on the nematodes from mangrove swamps of deltaic Sundarbans, West Bengal, India. (III) Anoplostoma macrospiculum $\mathrm{n}$. sp. (Anoplostomatidae: Nematoda) // Current Science. Vol.56. P.539-540.

Schuurmans Stekhoven J.H. 1942. The free living nematodes of the Mediterranean. II. The Camarque // Zoologische Mededeelingen, Leiden. Bd.23. S.229-262.

Timm R.W. 1952. A survey of the marine nematodes of Chesapeake Bay, Maryland // Contributions of Chesapeake biological Laboratory. Vol.95. P.1-70.

Timm R.W. 1967. Some estuarine nematodes from the Sunderbans // Proceedings of Pakistan Academy of Sciences. Vol.4. P.1-13.

Wieser W. 1953. Free-living marine nematodes. I. Enoploidea // Lunds Universitets Årsskrift. N. F. Avd. 2. Bd.49. No.6. S.1-155.

Responsible editors: Frank D. Ferrari, Viatcheslav N. Ivanenko 